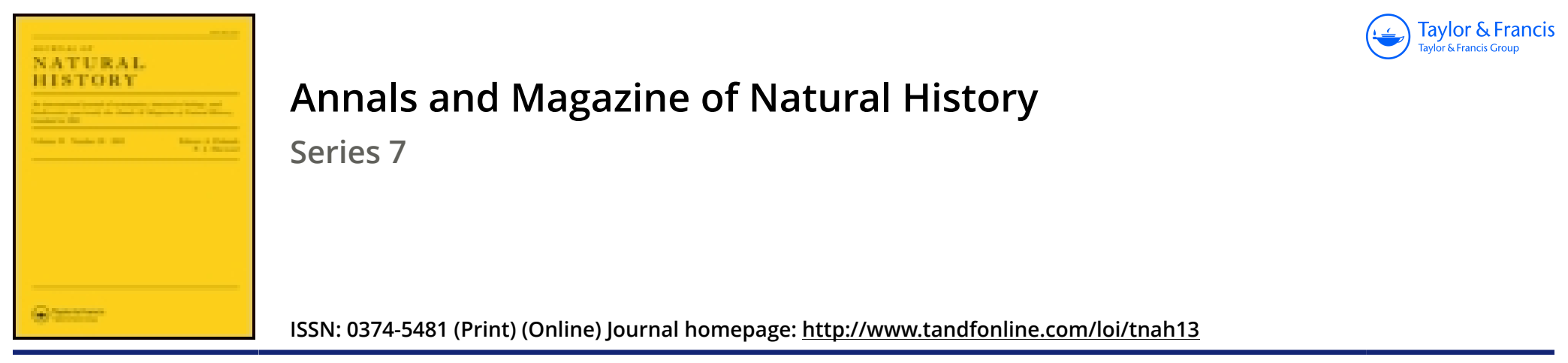

\title{
LI.--Remarks on secondary sexual differences in Rutelid Coleoptera, with descriptions of some new forms
}

\section{Gilbert J. Arrow}

To cite this article: Gilbert J. Arrow (1901) LI.-Remarks on secondary sexual differences in Rutelid Coleoptera, with descriptions of some new forms, Annals and Magazine of Natural History, 7:41, 393-401, DOI: 10.1080/00222930108678492

To link to this article: http://dx.doi.org/10.1080/00222930108678492

曲 Published online: 28 Sep 2009.

Submit your article to this journal $\pi$

Џll Article views: 5

Q View related articles $\square$

7 Citing articles: 1 View citing articles $\square$ 


\section{THE ANNALS}

\section{AXD \\ MAGAZINE OF NATURAL HISTORY.}

[SEVENTH SERIES.]

No. 41. MAY 1901.

\section{LI.-Remarlss on Secondary Sexual Differences in Rutelid} Coleoptera, with Descriptions of some new Forms. By Gilbert J. ArRow.

THE sexual differences of the Adoreti have as yet received no attention, although the neglect of them has added to the difficulty of establishing order in the nomenclature of this muchconfused group of Rutelidæ. There are a number of extremely similar African species of Adoretus, characterized by a broad clypeus and close grey pubescence, amongst which are a few erect setæ. The separation of these has been found a matter of the greatest difficulty, but there is a structure found in the males attention to which will, at any rate, very considerably obviate this. The male of Adoretus xanthochrous, Har. (testaceus, Fåhr.), found in Natal, has the hind trochanters produced into a long spine, which has been described as a specific character. It seems to have been overlooked that it occurs in only one sex.

'The male of the West-African $A$. hirtellus, Lap., has a similar long spine, but consisting in this case of a sharp projection from the femur. It is represented in the female by a slight and not acute prominence.

In $A$. vestitus, Reiche (Abyssinia), this sexual structure is represented by a triangular plate which occupies the Ann. \& Mag. N. Hist. Ser. 7. Vol. vii. 
same position. These two species are otherwise scarcely distinguishable.

The East-African $A$. punctipennis, Făhr., another species of almost identical appearance, may be distinguished from those just referred to by the entire absence in both sexes of any armature of this kind. In a former paper dealing with Rutelid Coleoptera from the Transvaal (Ann. \& Mag. Nat. Hist. (7) iv. p. 120), regarding all the unarmed specimens as females, I failed to distinguish these two species, and referred a specimen of $A$. punctipennis to the West-African species. The range of these insects is therefore still less wide than I there stated. A. punctipennis, Fahr., though distinct from $A$. hirtellus, Lap. (=cinerarius, Burm.), is, I believe, identical with $A$. cephalotes, Gerst.

In all these forms the two sexes are closely similar and the appearance of both that of typical Adoreti; but there are members of the group in which the male characters are greatly exaggerated, the hind legs being of enormous size and the characteristic appearance of the ticue Adoretus almost lost. One of these is $A$. albosetosus, Waterh. (which has been twice redescribed by $\mathrm{M}$. Fairmaire under the names of albohispidus and hystrix). For this a new genus will have ultimately to be formed, but I do not propose to do this at present, as I have not yet been able to see the female, which appears to be much rarer than the male.

An East-African insect not very distantly related to the last has been described by Herr Brenske under the name of Trigonochilus coriaceus. The author was evidently not acquainted with the nearest allies of this remarkable beetle, for he has formed a new subfamily for it. Had the fermale only been known, however, the species would no doubt have been placed in the genus Adoretus, the peculiarities which have induced its separation virtually all resulting from the great developments peculiar to the male. Here again there is a strong spine upon the lower edge of the hind femur, which, with the tibia, is greatly enlarged, as in $A$. albosetosus.

In the British Museum is an undescribed species from Angola, which, although differing considerably in general appearance from $T$. coriaceus, may well be placed in the same genus. The two sexes of this show similar remarkable differences.

\section{Trigonochilus politus, sp. n.}

Breviter ovatus, nitidus, rufo-testaceus; capite rugoso-punctato; prothorace parvo, lateribus valde arcuatis, longe flavo-hirtis, marginibus reflexis, angulis posticis rotundatis, disco fere polito; 
scutello flavo-setoso, cordiformi; elytris leviter parun dense punctatis; pygidio cum abdominis dorso flavo-pubescentibus; corpore subtus fere nudo, cum pedibus ferrugineis.

Long. 10.5-12.5 mm.

$\delta$, elytris basi vage infuscatis, subtilissime punctatis, pilis brunneis longissimis parce hirtis; pedibus postice valde incrassatis, femoribus dilatatis spina longa recta munitis, tibiis curratis, apice intus longissime et acute productis, tarsis quam tibiis paulo brerioribus. o, thorace basi fortius contracto, punctis disco nonnullis magnis; elytris magis punctatis, minute et parcissime flavo-setosis, pone medium maculis parvis 4 prope margines formantibus.

Hab. Angola.

This species is of a shorter and more oval form than $T$. coriaceus and of a brick-red colour. The upper surface in the female is decorated with minute scaly setæ, collecting on the posterior half of the elytra into rather indefinite yellow spots. In the male these setæ are replaced by very long
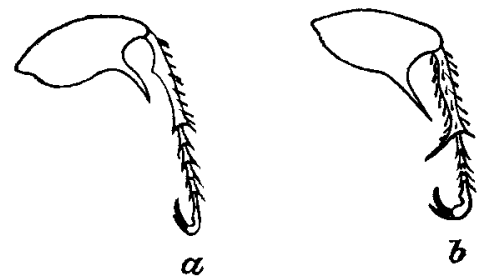

Hind legs of males of (a) Trigonochilus coriaceus, Brenske, (b) $T$. politus, Arrow. Twice natural size.

hairs thinly scattered over the prothorax and elytra. In the female the hairs are much shorter and confined to the margins. The prothorax of the male is flatter and less narrowed behind than in the other sex and the elytra are darker at the base. The hind legs show a similar development to those of $A$. coriaceus, but the femoral spine is straight, the tibia is produced at the extremity into a very long spur, and the tarsus is scarcely as long as the tibia.

I have sketched the hind legs of the males of these two species for the sake of comparison. Herr Brenske's figure of the type species gives a scarcely correct impression of its appearance, as was almost inevitable, since the artist did not see the insect.

A little more attention given to the sexual characters of the genus Anoplognathus would have rendered the identification and classification of these beetles much simpler. Some of the 
species are unrecognizable from description owing to uncertainty as to the sex of the type, a point which can always be ascertained with very little trouble. These characters also form a more natural and useful basis of subdivision than those which have been employed.

The proper allocation of the species between the genera Calloodes and Anoplognathus has vexed the minds of all who have dealt with these insects, partly owing to the rarity of the type species of the former genus, but also through oversight of the sexual differences, which has led to forms of very varied type being assigned to it by different authors. Examination of both sexes of Calloodes grayanus, White, shows it to possess, in common with its immediate allies, peculiarities in the form of clypeus and tibia which quite clearly separate them from all other forms.

To set this matter at rest I shall for the first time formally characterize this genus, drawing up the diagnosis from White's type (which is a female) and a male of the same species.

\section{Calloodes.}

Regulariter ovatus, subdepressus. Clypeus utroque sexu brevis recte truncatus, margine reflexa ; maris angulis minus rotundatis, margine magis reflexa. Prothoracis margo postica ante seutellum profunde excisa, ad emarginationis latera acute angulata. Tibiæ anticæ edentatæ, latere externo maris recto, feminæ leviter bisinuato. Processus mesosternalis longus, validus, fere rectus.

The known species of this genus are grayanus, White, Rayneri, McLeay, and Atkinsoni, Waterhouse, all others assigned to it being entirely different in essential characters. Mr. Blackburn, who last attempted to define the genus, although believing he knew all the species, had evidently seen none of these three, for he finds the principal generic characteristic to be the possession of "genuinely metallic" colours, whereas all are unmetallic green.

I may note that $C$. grayanus has a cleft claw to the front tarsus in the female, while in the other species all claws are undivided in both sexes.

The following new species of Anoplognathus may be described here :-

\section{Anoplognathus luridus, sp. n.}

Breviter ovatus, brunneus; capite, prothorace, scutello, pygidio, femoribus tibiisque igneo-metallicis, corpore subtus metalliconigro, tarsis nigro-viridibus; clypeo breri, cum fronte paulo 
punctato, nitido, maris parte media nonnihil producta, reflexa; prothorace nitido, vix punctato, lateribus paulo arcuatis, angulis anticis acutis, posticis fere rectis, marginis anticæ medio sat profunde ante scutellum exciso, angulis rotundatis; elytris subdense non confluenter punctatis, punctis majoribus seriato-ordinatis interpositis, apicibus paulo productis, subtiliter rotundatis; pygidio fere lrevi, punctis magnis setisque nonnullis; corpore subtus fere nudo, processu mesosternali longo, acuto, tibiis anticis 3-dentatis.

Long. $22 \mathrm{~mm}$.

Hab. New South Wales.

This insect is intermediate between $A$. rugosus, Kirby, and A. chloropyrus, Drap., its colouring being almost that of the former and its form and sculpture more those of the latter, but showing an approximation to $A$.rugosus. The clypeus is as in $A$. chloropyrus, but the sternal process is stronger, there is no definite striation upon the elytra, of which the sutural angles are slightly produced and not squarely truncate, and the sculpturing of the pygidium is only incipient.

\section{Anoplognathus explanatus, sp. n.}

Ovoidalis, depressus, postice latus, brunneo-testaceus, lævissime purpureo-nitens; capite, prothorace scutelloque paulo æneis, pygidio fusco-viridi, corpore subtus nigro, femoribus tibiisque rufis, tarsis nigro-viridibus, capite, prothorace, scutello suturaque anguste nigro-marginatis; capite punctato-rugoso, clypeo maris producto, quadrato, hirto, margine antica tota reflexa, feminæ semicirculari; prothorace transverso, maris paulo angustiore, leviter punctato, angulis anticis crebrius, his flavo-hirtis, acutis, angulis posticis fere rectis, lateribus angulatis vix arcuatis, margine postica ante scutellum leviter excisa; scutello subtiliter punctato; elytris sublineato-punctatis, ad humeros prothoracis latitudine, deinde ad post medium valde dilatantibus (maris paulo minus), costa laterali ad marginem parallela, angulis suturalibus separatim sat minute rotundatis; pygidio rugoso, parce flavohirto; corpore subtus (abdominis medio excepto), femoribus tibiisque intus flavo-hirtis, mesosterno crebre punctato, breviter acuto, tibiis anticis 3 -dentatis.

Long. $23 \mathrm{~mm}$.

\section{Hab. New South Wales.}

This is a member of the section represented by $A$. suturalis, Boisd., and $A$. hirsutus, Burm., as indicated by the hairy squarely-produced clypeus of the male. It is readily distinguished, however, from these, as from all other described species, by its peculiar pear-shaped outline and the prominent costa running near and parallel to the margin of each elytron. 
The purplish lustre characterizing all the specimens I have seen may, perhaps, not be absolutely constant, but another feature distinguishing this species from the two just mentioned is presented by the apices of the elytra, which are separately rounded.

Although these three insects are the only described species of this section of the genus, it consists of a number of closely related forms. As 1 am not able to decide with certainty which of these is Burmeister's species, it would be unwise to attempt at present to name the other nondescripts.

Another beautiful Australian Rutelid, also sexually dimorphic, requires further description. This is the Popillia favomaculata of McLeay, a species probably described from a single specimen and quite erroneously placed. Specimens of this insect have lately been brought from Mount Bellenden Ker, in North Queensland, and it was only by an accident that I was led to consult McLeay's description, for neither in form nor structure has the species any resemblance to Popillia, a genus which is not known in Australia. The rather depressed and elliptical form and pubescent surface of flavomaculata distinctly suggest $A$ doretus, but its mouth-parts disprove any such affinity. The flat prosternal process upstanding behind the coxæ is known elsewhere among Rutelidæ only in the genus Mimela, but the ten-jointed antennæ, as well as its entire aspect, seem to exclude this insect from the Anomalinæ. Although I am unable to pronounce upon the true place of this new genus in the family, its remarkable combination of characters, together with the peculiar beauty of its colour and marking, will make it quite easy of identification when rescued from the obscurity of a great genus to which it does not belong.

\section{Mimadoretus, gen. nov.}

Ellipticus, subdepressus. Clypeus subquadratus, transversus. Labrum simplex, late emarginatum. Maxillæ 3-dentatæ, palporum articulo ultimo grandi, fusifor mi, longitudine ad reliquos æquali. Labium latum, margine paulo concava. Antennæ 10-articulatæ, clara triphylla, parum elongata. Prosternum post coxas prominens, cuneiforme. Metasternum inter coxas medias acutum, non productum. Pedes omnes robusti. Tibiæ anticæ fortiter bidentatæ. Maris ungues integri, feminæ pedis antici externus fissus.

The type of Mimadoretus flavomaculatus is evidently a female, in which sex the upper surface is of a light mahoganycolour, with a metallic lustre, especially upon the prothorax. 
In the male, however, the elytra are almost black, shining but quite unmetallic. In both there is a similar pattern of yellow scaly hairs which cover the pygidium and under surface. It is quite a small beetle, about 8 millimetres long.

The following two new species of Pseudosinghala are remarkable for colour-differences between the two sexes. These are of the nature which I have previously described as general in the Anomalinæ, viz. the males are invested with a hue superimposed upon that of the females.

\section{Pseudosinghala regalis, sp. $\mathrm{n}$.}

Curta, robusta, testacea; corpore antice et subtus brunneo, tibiis tarsisque fere nigris, maris capite, prothorace, scutello, pygidio, corpore subtus femoribusque igneo-metallicis, feminæ corpore subtus femoribusque solum leviter æneis; capite dense rugoso, clypeo late arcuato ; prothorace valde convexo, grosse punctato, postice sat disperse, lateribus margineque postica fortiter ac equaliter arcuatis, hac utrinque impressa, angulis anticis acutis, posticis valde obtusis; scutello late cordiformi, vix punctato; elytris brevibus, testaceis, grosse lineato-punctatis, punctis ocellatis, macula transversa basali, scutellum amplectente, sutura, plagisque humerali et postica obliqua nigris, punctis flavis duobus (nonnunquam bisectis) parvis ad suturam ante medium; pygidio magno, grosse punctato; tibiis anticis fortiter bidentatis, pedum 4 anteriorum unguibus externis fissis ; corporis subtus lateribus parce pilosis.

Long. 8.5-10 mm.

\section{Hab. Penang.}

This is the largest Pseudosinghala yet known. It is stout and globular, with the sides of the thorax more strongly curved than in any other species known to me. The elytra in both sexes are of a rich testaceous colour, with a small yellow spot (sometimes divided) on each side of the suture before the middle, and nearly the entire margin black, together with a transverse patch round the scutellum, which may extend right across the elytra. 'The difference between the sexes is that, while in the female the head, thorax, and scutellum are of a very dark brown colour, in the male they are suffused with a brilliant fiery lustre. The pygidium of the latter also has a similar lustre, whereas in the fernale it is, with the rest of the abdomen, unmetallic red.

A series of specimens in the British Museum were collected by the late Mr. Lamb, and the species is also in Mons. R. Oberthür's collection. 


\section{Pseudosinghala conjuga, sp. $\mathbf{n}$.}

Breviter cylindrica, pallide testacea, ubique metallico-nitens; prothorace (lateribus exceptis), scutello, elytrorum sutura (antice et postice latius), abdominis medio, tibiis tarsisque maris nigro-æneis, feminæ rufo-testaceis; capite rugoso, clypeo late arcuato; prothorace valde convexo, subtiliter punctato, margine postica regulariter arcuata, lateribus fortiter arcuatis, angulis anticis acutis, posticis valde obtusis ; scutello fere æqualiter trilaterali, vix punctato; elytris fortiter punctato-striatis, macula lata suturali vix ad margines anticam et posticam attingente medio utrinque abrupte interrupta; pygidio disperse punctato, cum pectoris et abdominis lateribus femoribusque pallidis; corpore toto nudo; tibiis anticis fortiter bidentatis, tarsorum 4 anteriorum unguibus externis fissis.

Long. $6 \mathrm{~mm}$.

Hab. S. India, Nilgiri Hills.

In this species there is a slight metallic gloss over the entire surface, but the dark markings are in the male deep blackish bronze and in the female reddish, becoming in the latter regularly paler from the head backwards, until the posterior division of the broad sutural mark becomes indistinguishable from the testaceous ground-colour. The femora in both sexes are pale and the tibix and tarsi of the colour of the dorsal markings according to the sex.

As the result of a study of further examples I have to confess to having, in the case of Hylamorpha rufimana, Arrow, fallen into the trap against which 1 have warned others, this being nothing bat a sexual form-the female of H. elegans, Burm. My error is due to the fact that the two specimens from which my description was drawn up were from a separate collection, and the only two females in the British Museum collection, as compared with a large series of the other sex. This is very strange, especially as in a collection lent to me by Mr. H. S. Gorham, which I have recently examined, the males are less than twice as numerous as the females. Burmeister apparently did not know the latter, for he has described the sexes as " $q$ bright green; $\delta$ with legs and elytra olivaceous," which is quite wrong, the discoloured forms occurring equally in both sexes. The real distinction consists in the front legs of the female being of a castaneous colour and the middle and hind tibia brilliant golden green. The front tibix are also shorter and more strongly toothed in this sex, the third tooth being past the middle. In the male 
all the legs are unmetallic green and the front tibiæ slightly toothed on the distal half only.

The discoloration regarded by Burmeister as a sexual peculiarity may possibly be due to immaturity or to the action of preservatives. I have seen it in all stages, and it appears to be one of these imperfect specimens which has been honoured with specific rank by Herr Nonfried, under the name of Sulcipalpus subviolaceus.

Dr. Ohaus has kindly pointed out to me that a nameAnomala solida-used by me in a previous paper ('Trans. Ent. Soc. Lond. 1899, p. 257) dealing with sexual dimorphism in the Rutelidre is occupied by a species of Erichson's placed as synonymous with $A$. anea by Gemminger and Harold, but regarded as distinct by $\mathrm{Dr}$. Ganglbauer. I therefore rename my species Anomala mutata.

LII.-Descriptions of Genera and Species of Coleoptera from South Africa. By H. S. Gorham, F.Z.S. \&c.

[Concluded from p. 365.]

Fam. Endomychidæ.

Ancylopus bisignatus, Gerst. Mon. Endom. p. 192.

Hab. Mashonaland, Salisbury, in marsh-rubbish (Marshall). Three males.

These seem to differ a little from Senegal specimens by their darker red colour and by the base of the elytra being narrowly and indeterminately black. The legs are also very dark. Gerstaecker, by an error, says the middle tibiæ in the male are toothed; it is, of course, the front tibix, and the middle pair only, as he afterwards says, bent near their apices.

Ancylopus unicolor, Gerst. Mon. Endom. p. 194.

A single male specimen without the locality, but I believe from Salisbury with the preceding. 'The front and middle tibiæ are both toothed, as they are in $A$. melanocephalus $\delta$.

CEdiurthrus natalensis, Gerst. Mon. Endom. p. 346, t. iii. fig. 5 .

Hab. Mashonaland, Salisbury, "in a swamp" (Marshall). 